Revista Brasileira de Higiene e Sanidade Animal Brazilian Journal of Hygiene and Animal Sanity ISSN: 1981-2965

\title{
Evaluation of the transmission of Bovine Viral Diarrhea Virus by transplacental route in pregnant females experimentally inoculated
}

Avaliação da transmissão do Vírus da Diarreia Viral Bovina pela via transplacentária em fêmeas gestantes inoculadas experimentalmente

\section{Beatriz Belloni Zambotti ${ }^{1}$, Mariela Aparecida Claro Martines ${ }^{2}$, Marina Lopes Mechler Dreibi $^{3}$, Gabriel Yuri Storino ${ }^{4}$, Marcela Manduca Ferreira ${ }^{5}$, Luís Guilherme De Oliveira $^{6}$}

\begin{abstract}
Pigs, in natural conditions, can become infected with the bovine viral diarrhea virus (BVDV), a pestivirus of ruminants that leads to reproductive and economic losses. The final third of pregnancy is a critical period for gilts due to stress and the consequent immunological drop. Thus, the objective was to promote the experimental inoculation of gilts with BVDV-2 and to evaluate the capacity of virus transmission to fetuses in a critical period of stress and immunosuppression. Six pregnant gilts were inoculated between the 105th and 110th day of gestation, the piglets born underwent blood collection (to obtain whole blood and serum) and an umbilical cord fragment at birth prior to colostrum ingestion, and had blood collected weekly up to 21 days of age. Samples from all placentas were also collected. Two gilts composed the control group, and their piglets underwent the same procedures. The blood, umbilical cord and placental fragments samples were submitted to RT-PCR evaluations, while the serum was evaluated by the virus neutralization test. There was no evidence of viral transplacental transmission to fetuses in the evaluated period.
\end{abstract}

Keywords: BVDV, experimental inoculation, piglets, reproductive losses

Resumo: Os suínos, em condições naturais, podem se infectar pelo vírus da Diarreia Viral Bovina (BVDV), um pestivírus de ruminantes que leva a perdas reprodutivas e econômicas. Em suínos, a infecção pelo BVDV não está bem elucidada, mas estudos em bovinos mostram que o vírus é capaz de atravessar a barreira transplacentária e infectar leitões em desenvolvimento. Este estudo teve como objetivo promover a inoculação experimental de marrãs com o BVDV-2 e avaliar a capacidade de transmissão aos fetos. Seis fêmeas gestantes foram inoculadas entre o $105^{\circ}$ e $110^{\circ}$ dia de gestação, e os leitões nascidos passaram por coleta de sangue (para obtenção de sangue total e soro) e fragmento de cordão umbilical ao nascimento, antes da ingestão do colostro, e tiveram sangue colhido semanalmente até os 21 dias de idade. Amostras de todas as placentas também foram coletadas. Duas fêmeas compuseram o grupo controle, e os leitões passaram pelos mesmos procedimentos. As amostras de sangue, cordão umbilical e fragmentos de placenta foram submetidos a avaliações de RT-PCR, enquanto que o soro foi avaliado por virusneutralização.

Palavras-Chave: BVDV, inoculação experimental, leitões. 
http://dx.doi.org/10.5935/1981-2965.20200013

1 Graduanda em Medicina Veterinária pela Universidade Paulista Júlio de Mesquita Filho (UNESP) Jaboticabal - beatrizbelloni@outlook.com

2 Graduanda em Medicina Veterinária pela Universidade Paulista Júlio de Mesquita Filho (UNESP) Jaboticabal-marry_1509@hotmail.com

3 Médica Veterinária e Doutoranda pela Universidade Paulista Júlio de Mesquita filho (UNESP) Jaboticabal - mlopesvet@gmail.com

4 Médico Veterinária e Doutorando pela Universidade Paulista Júlio de Mesquita filho (UNESP) Jaboticabal-gystorino@gmail.com

5 Médica Veterinária e Mestranda pela Universidade Paulista Júlio de Mesquita filho (UNESP) Jaboticabal - marce.manduka@ hotmail.com

6 Professor Doutor pela Universidade Paulista Júlio de Mesquita filho (UNESP) - Jaboticabal luis.guilherme@unesp.br

${ }^{123456}$ Department of Veterinary Clinic and Surgery, College of Agricultural and Veterinary Sciences (FCAV), São Paulo State University (Unesp), Via de Acesso Prof. Paulo Donato Castellane s/n, Jaboticabal, SP 14884-900, Brazil.

\section{Introduction}

The genus Pestivirus, belonging to the family Flaviviridae, has viral species of great importance for animal production, such as the bovine viral diarrhea virus (BVDV) 1 and 2, classical swine fever virus (CSFV) and the border disease virus (BDV). As classified by the ICVT (International Committee on Taxonomy of Viruses), these species are today named as Pestivirus A, B, C and D, respectively. The bovine viral diarrhea virus (BVDV) can be classified into two different biotypes according to the effect of viral replication on cultured cells: cytopathic (CP) and noncytopathic (NCP) (LINDENBACH \& RICE, 2001). NCPs are capable of producing persistent infection in infected bovine fetuses between 40 and 120 days of pregnancy, and are most commonly found in the field, while CPs are considered a mutation of the NCP biotype and are therefore less common in nature (RIDPATH et al., 2012). It is an enveloped virus, single-stranded RNA genome (FRANCKI et al., 1991) and constituted of two different genotypes, 1 and 2 (FLORES et al., 2005; CORTEZ et al., 2006; LUNARDI et al., 2008).

BVDV-1 is related to milder and moderate infections, described as classic virus samples or reference strains (FLORES et al., 2000), BVDV-2 is associated with high morbidity and mortality in cattle, leading to respiratory or enteric, reproductive problems, hemorrhagic disease and thrombocytopenia (BRUM et al., 2013). BVDV mainly affects cattle, but also sheep, pigs, goats and other wild animals (RIDPATH 2010). Recent studies have also demonstrated the first molecular evidence of the presence of BVDV in wild boars (WEBER et al., 2016). The first records of infection in pigs 
occurred in the 1960s (SNOWDON \& FRENCH, 1968). In Brazil, Gatto (2015) and Almeida (2017) registered the occurrence of the virus in technically farmed and subsistence pigs, respectively, between 2014 and 2015 in the northeast region of the same state. Despite this, studies on the prevalence of BVDV in pig farming are still scarce compared to studies in cattle.

BVDV infection can occur under natural conditions, directly or indirectly between animals, through nasal, oral, ocular and genital secretion or urine, feces, semen and milk; by experimental infection (Mengeling, 1988) and by exposure to classical swine fever vaccines contaminated by BVDV (FAN et al., 2010). Vertical transmission also occurs, and the birth of persistently infected animals (PI) is responsible for maintaining the virus in a population. In cattle, this condition occurs when a pregnant cow is infected in the middle third of gestation (40 to 120 days). During this period, the fetus' immune system is not yet fully developed and the virus is then recognized as its own, making the fetus immunologically tolerant (Brock, 2003), which means that PI animals shed large amounts of viruses without the development antibodies.

In other studies, experimental infections were performed in pregnant sows and transplacental transmission has been reported. In a study where pregnant sows were inoculated with BVDV on the 35th and 45th day of gestation by intrauterine and intranasal route, respectively, nine piglets born from gilts infected by intrauterine route and five born from animals infected by intranasal route were born persistently infected (PATON \& DONE, 1994).

Conversely, a recent study analyzed a group of gilts inoculated by BVDV via oronasal on the 45th day of pregnancy, in which no transplacental transmission was found. At birth, the animals did not show antibodies to BVDV-2, which were later acquired by passive maternal transmission (MECHLER et al., 2018).

Infection caused by CSFV is a mandatory reportable disease, and as the virus belongs to the same family as BVDV, they are antigenically and genetically related. Because they share such common antigenic structures, the serological tests used to detect CSFV can cross-react with antibodies against BVDV, resulting in false-positive reactions, which may interfere in the official disease monitoring programs. In naturally infected young piglets, the disease progresses without clinical signs, but in adult animals mainly reproductive problems such as birth of weak piglets, abortion and fetal 
mummification have been reported (VANNIER et al., 1988). Considering the abovementioned information, this project aimed to evaluate the possibility of transplacental transmission of BVDV-2 in gilts experimentally inoculated in the final third of gestation.

\section{Material and Methods}

Ethics statement: The experiment was conducted at the Swine Medicine Laboratory, School of Agricultural and Veterinarian Sciences (FCAV), Jaboticabal/SP, Brazil, according to the Ethical Principles in Experimentation, approved by the Ethics Committee on the Use of Animals (CEUA/Protocol \#01334718).

Animal housing: Eight Large White gilts from commercial lineage were acquired from a specialized company. The inoculated group was composed by six gilts $(\mathrm{G} 1 ; \mathrm{n}=6)$, and the control group by two gilts $(\mathrm{G} 2 ; \mathrm{n}=2)$, with the control and infected groups being kept in separate environments, in order to avoid BVDV infection of free animals. The gilts were fed according to the gestational phase, and water was offered ad libitum. The birth was assisted to ensure the necessary care and blood collection of newborns before colostrum intake.

Viral inoculation: The inoculum was prepared by the Biological Institute of
São Paulo, which isolated BVDV-2 from field clinical case of bovine viral diarrhea in cattle (FLORES et al 2005). Each gilt received a viral dose of BVDV-2 with titer of $10^{5,5} \mathrm{TCID}_{50} / \mathrm{mL}$, cultured in MBDK cells in $15 \mathrm{ml}$ of EMEM (Eagles Minimal Essential Medium). Inoculation was performed via the oronasal route in the six pregnant gilts at the 105th day of gestation, with $5 \mathrm{ml}$ being instilled by the oral route, and $5 \mathrm{ml}$ administered in each nostril. Gilts were observed for clinical and reproductive changes daily after virus inoculation. If any animal had an abortion, the expelled material (fetuses and placenta) would be subjected to analysis by RT-PCR.

Sample collection: Blood samples from piglets were collected with a sterile disposable syringe, free of anticoagulants, by puncture of the jugular vein with $25 \times 7$ needles on days $0,7,14$ and 21 . The blood was deposited in sterile tubes with EDTA to obtain whole blood; and in clot activator tubes followed by centrifugation at 15,000 $\mathrm{x} \mathrm{g}$ for 10 minutes to obtain blood serum.

The whole blood and serum samples were aliquoted in duplicates in DNAse and RNAse-free graduated microtubes, stored in a freezer at $-80^{\circ} \mathrm{C}$ and $-20^{\circ} \mathrm{C}$, respectively, until the moment of analysis. Samples of whole blood, umbilical cord and placenta collected were submitted to RT-PCR, while the serum was 
submitted to virus neutralization test.

Virus neutralization test: The serum samples were tested at the same time, subjected to successive dilutions from 1:10 to 1: 5120. Samples that presented total neutralization of 100 $\mathrm{TCID}_{50}$ of BVDV-2 in a concentration above 1:10 were considered positive. All procedures were made according to the recommended by the "Manual of Diagnostic Tests and Vaccines of Terrestrial Animals" (OIE, 2019), except that the samples were processed in duplicates. For the test, bovine kidney epithelial cells of the Madin-Darby Bovine Kidney strain (MDBK) were used and the cytopathic BVDV-2 (cp) virus was the standard virus.

RT-PCR: The fragments of placenta, umbilical cord and whole blood samples were evaluated for detection of BVDV fragments by RT-PCR. The RNA of the samples was extracted using Tri reagent (Sigma) and transcribed in cDNA using the kitHigh-Capacity cDNA Reverse Transcription (Applied Biosystems), according to the manufacturer's instructions. For BVDV detection, the pair of primers 103 (5'- TAG CCA TGC CCT TAG TAG GAC - 3') and 392 (5'- ACT CCA TGT GCC ATG TAC AGC - 3') was used, which amplifies a 290 bp product (Weinstock et al., 2001). The PCR reactions were composed of buffer $1 \mathrm{X}$ (KCl 50 mM, Tris-HCl 200 mM pH 8,4); $\mathrm{MgCl} 22 \mathrm{mM}$; dNTP's 0,2 mM, 1,0U of Taq DNA polimerase, 5 pmol of each primer, $3 \mu \mathrm{L}$ of RT-PCR product and sterile pure water for a final volume of 20 $\mu \mathrm{L}$. For amplification, a thermocycler was programmed to perform a cycle at $95^{\circ} \mathrm{C}$ for 5 minutes, 35 cycles at $94^{\circ} \mathrm{C}$ for $30 \mathrm{sec}$, $58^{\circ} \mathrm{C}$ for $30 \mathrm{sec}, 72^{\circ} \mathrm{C}$ for $40 \mathrm{sec}$, and a final cycle at $72^{\circ} \mathrm{C}$ for 10 minutes. The PCR products were subjected to a second amplification using the same protocol described above. The products of the second amplification were submitted to electrophoresis on a $1 \%(\mathrm{w} / \mathrm{v})$ agarose gel containing ethidium bromide $\left(0.5 \mathrm{mg} \cdot \mathrm{mL}^{-1}\right)$ and a 100 bp DNA Ladder Plus molecular size standard (Thermo Scientific), which were visualized under UV light, in photodocumentation equipmentGEL DOC XR (BioRad).

\section{Results}

Virus neutralization test: Serological analyzes showed that gilts did not develop antibodies against BVDV-2, as well as piglets, in none of the samples evaluated on the different days of collection.

RT-PCR: The presence of viral RNA was not detected by RT-PCR in blood, umbilical cord and placenta samples. 
Control animals were negative in all tests.

\section{Discussion}

BVDV infection in young pigs can occur without clinical manifestation of the disease (WALZ et al., 2004), but some authors have reported the triggering of reproductive problems in adult gilts, contemplating abortions, birth of small and stillborn piglets (BECHER et al., 2003). In this work, the inoculated gilts maintained the pregnancy without complications, as observed by Mechler et al. (2018) and PEREIRA et al. (2018). Unlike the observed in experimental infections with BVDV-2 in ruminants, the results of this study do not make it possible to state that there is transplacental transmission of this viral agent to fetuses during the final stage of pregnancy, since the presence of viral RNA was not detected by RT -PCR, nor antibodies against BVDV-2 by the virus neutralization technique.

From this, two possibilities can be outlined regarding the results obtained. The first concerns the BVDV-2 short and transient viremia characteristic, which can occur in pigs, making it difficult to detect viral RNA by RT-PCR in blood samples but does not necessarily imply the absence of viremia in piglets. The second is that the systemic spread of the virus in the gilt may not have been sufficient to overcome the transplacental barrier. It may be due to the epitheliocorial characteristic of swine placenta, with a primary function of uterine protection against pathogens, corroborated by the absence of viral RNA in the placenta and umbilical cord samples.

Regarding the results of virus neutralization, in a previous study of experimental inoculation of BVDV-2 in gilts, it was observed that the average period of seroconversion of the gilts challenged with the virus was 20 days (Mechler et al., 2018), varying between 12 and 33 days (PEREIRA et al., 2018). Taking into account that (i) the gilts were challenged close to delivery; (ii) the lactation period was 21 days; (iii) the immunoglobulins in breast milk are less concentrated at the end of lactation (LANZA et al., 1995); and (iv) there is individual variation in the immune response against BVDV-2, the nondetection of antibodies against the virus in piglets, observed in VN may be a consequence of this series of factors.

Also in Mechler et al. (2018), the authors observed that piglets born from gilts inoculated in the middle third of gestation did not present antibodies against the virus at birth, but they were acquired through passive colostral transfer, which declined over the lactation period.

In addition, BVDV is characterized by a predilection for replication in defense cells, mainly lymphocytes, but it also 
infects monocytes and dendritic cells. Dendritic cells act as antigen presenters, and play an important role in the development of cellular immunity, by initiating the non-specific immune response against various pathogens (Chase, 2013). The immune system's evasion mechanism against BVDV infection is monocyte lysis, which makes it difficult to recognize and subsequently develop a specific immune-humoral response (Iwasaki et al 2010). The data are in agreement with the literature, in which experimental infections from previous studies demonstrated hat BVDV in pigs leads to a milder and more irregular immune response (Almeida et al., 2018; Mechler et al., 2018; Pereira et al., 2018), when compared to cattle (HOUE, 1995).

No clinical signs were observed in animals infected with BVDV-2, which is in accordance with previous studies that demonstrated that experimental BVDV-2 infection in pigs has no clinical manifestation of the disease. (STORINO et al., 2019; MECHLER et al., 2018; PEREIRA., et al 2018).

Although BVDV does not pose a threat to pig herds, the presence of the virus in the herd can culminate in a serological cross-reaction with the CSFV, interfering negatively in the classical swine fever monitoring and surveillance programs, and leading to diagnostic confusions of the disease (LOEFFEN et al., 2009).

The experimental inoculation of gilts in the final third of gestation showed that there was no development of antiBVDV-2 antibodies, nor transplacental transmission of BVDV-2 to the born piglets.

\section{Conclusion}

The experimental inoculation of gilts in the final third of gestation showed that there was no development of antiBVDV-2 antibodies, nor transplacental transmission of BVDV-2 to the born piglets.

\section{Acnokledgements}

To the São Paulo State Research Foundation (FAPESP) for granting \#2018/20841-3.

\section{References}

1. ALMEIDA, H.M.S.; GATTO, I.R.H.; SANTOS, A.C.R.; FERRAUDO, A.S.; SAMARA， S.I.; OLIVEIRA， L.G. A Cross-Sectional and Exploratory Geospatial Study of Bovine Viral Diarrhea Virus (BVDV) Infections in Swines in the São Paulo State, Brazil. Pak. Vet. J. v.37, p.470-474, 2017.

2. BECHER, P.; RAMIREZ, R.A.; ORLICH, M.; ROSALES, S.C; KÖNIG, M.; SCHWEIZER, M.; STALDER, H.; SCHIRRMEIER, H.; THIEL, H.J. Genetic and antigenic characterization of novel pestivirus genotypes: implications for classification. Virol. v.311, p.96-104, 2003. 
3. BROCK, K.V. The persistence of bovine viral diarrhea virus. Biologicals, v.31, p.133-135, 2003.

4. BRUM, J.S.; KONRADT, G.; BAZZI, T.; FIGHERA, R.A.; KOMMERS, G.D.; IRIGOYEN, L.F.; BARROS, C.S.L. Características e frequência das doenças de suínos na Região Central do Rio Grande do Sul. Pesq. Vet. Bra. v.33, n.10, p.12081214, 2013.

5. CHASE, C.C.L. The impact of BVDV infection on adaptive immunity.

Biologicals, v.41, n.1, p.52-60, 2013.

6. CORTEZ, A.; HEINEMANN, M.B.; DE CASTRO, A.M.M.G.; SOARES, R.M.; PINTO, A.M.V.; ALFIERI, A.A.; FLORES, E.F.; LEITE, R.C.; RICHTZENHAIN, L.J. Genetic characterization of Brazilian bovine viral diarrhea virus isolates by partial nucleotide sequencing of the 50 -UTR region. Braz. J. Vet. Res. v.26, p.211-216, 2006.

7. FAN, X. Z.; NING, Y.B.; WANG, Q.; XU, L.; SHEN, Q.C. Detection of bovine viral diarrhea virus as contaminant in classical swine fever virus live vaccine with RT-PCR. Chin. J. Vet. Med. v.46, p.8-10, 2010.

7. FLORES, E.F.; WEIBLEN, R.; SCHERER, C.F.C.; GIL， L.H.V.G.; PILATI, C.; DRIEMEIER, D.; MOOJEN, V.; WENDELSTEIN, A.C. Identificação do vírus da diarreia viral bovina tipo 2 (BVDV-2) no sul do Brasil. Pesq. Vet. Bras. v.2, n.20, p.85-89, 2000.

8. FLORES, E.F.; WEIBLEN, R.; VOGEL, F.S.F.; ROEHE, P.M.; ALFIERI, A.A.; PITUCO, E.M. A infecção pelo vírus da Diarréia Viral Bovina (BVDV) no Brasil - histórico, situação atual e perspectivas. Pesq. Vet. Bras. v.25, n.3, p.125-134, 2005.
9. FRANCKI, R.I.B.; FAUQUET, C.M.; KNUDSON, D.L.; BROWN, F. Classification and nomenclature of viruses. Fifth Report of the International Committee on the Taxonomy of Viruses. Arch. Virol. v.2, p.228-229, 1991.

10. GATTO, I.R.H.; HARMON, K.; BRADNER, L.; SILVA, P.; LINHARES, D.C.L.; ARRUDA, P.H.; ARRUDA, B.L. Detection of atypical porcine pestivirus in Brazil in the central nervous system of suckling piglets with congenital tremor. Transbound Emerg Dis v.65, n.2, p.375380, 2018.

11. HOUE, H. 1995. Epidemiology of Bovine Viral Diarrhea Virus. Vet Clin N Am - Food Animal Practice. v.11, n.3, p.521-547, 1995.

12. IWASAKI, A.; MEDZHITOV, R. Regulation of Adaptive Immunity by the Innate Immune System. Sci. v.327, n.5963, p.291-295.

13. LANZA, I.; SHOUP, D.I.; SAIF, L.J. Lactogenic immunity and milk antibody isotypes to transmissible gastroenteritis virus in sows exposed to porcine respiratory coronavirus during pregnancy. Am. J. Vet. Res. v.56, n.6, p.739-748, 1995.

14. LINDENBACH, B.D.; RICE C.M. Flaviviridae: the viruses and their replication. Virology, 4th ed. D.M. Knipe and P.M. Howley, editors. Lippincott Williams \& Wilkins, Philadelphia. p. 9911042., 2001.

15. LOEFFEN, W.L.A.; VAN, B.A.; QUAK, S.; ELBERS, A.R.W. Seroprevalence and risk factors for the presence of ruminant pestiviruses in the Dutch swine population. Vet. Microbiol. v.136, p.240-245, 2009. 
16. LUNARDI, M.; HEADLEY, S.A.; LISBÔA, J.A.N.; AMUDE, A.M.; ALFIERI, A.A. Outbreak of acute bovine viral diarrhea in Brazilian beef cattle: clinico pathological findings and molecular characterization of a wild-type BVDV strain subtype 1b. Res. Vet. Sci. v.85, n. 3, p.599-604, 2008.

17. MECHLER, M.L. Congenital tremor in piglets: Is bovine viral diarrhea virus an etiological cause?. Vet. Microbiol. v.220, p.107-112, 2018.

18. MENGELING, W. The possible role of bovine viral diarrhea virus in maternal reproductive failure of swine. Proc. Int. Pig. Vet. Soc. v.10, p.228, 1988.

19. OIE. Office International Dez Epizzoties - World organisation for Animal Health. Manual of Diagnostic Tests and Vaccines for Terrestrial Animals. $<$ http://www.oie.int/fileadmin/Home/eng/ Health_standards/tahm/2.04.07_BVD.pdf> . Acess in: March 19, 2020, 2019.

20. PATON, D.J.; DONE, S.H. Congenital infection of pigs with ruminant-type Pestiviruses. J. Comp. Patho. v.111, p.151-163, 1994.

21. PEREIRA, D.A.; PERON, J.B.; ALMEIDA, H.M.S.; BARALDI, T.G.; GATTO, I.R.H.; KASMANAS, T.C.; PITUCO, E.M.; MONTASSIER, H.J.; DE OLIVEIRA, L.G. Experimental inoculation of gilts with bovine viral diarrhea virus 2 (BVDV-2) does not induce transplacental infection. Vet. Microbiol. v. 225, p. $25-30,2018$.

22. RIDPATH, J.F 2010. Bovine Viral Diarrhea Virus: Global Status. Vet. Clin. N. Am. - Food Animal Practice, v.26, n. 1, p. 105-121.
23. RIDPATH, J.F.; BAUERMANN, F.V.; FLORES, E.F. Virologia Veterinária. 2th ed. Santa Maria: Editora UFSM, 2012. p.565-589.

24. SNOWDON, W.A.; FRENCH, E.L. The bovine mucosal disease-swine fever virus complex in pigs. Aust. Vet. J. v.44, p.179-184, 1968.

25. STORINO, G.Y.; XAVIER, E.B.; MECHLER-DREIBI, $\quad$ M.L.; SIMONATTO, A.; GATTO, I. R.H.; OLIVEIRA, M.E.F.; DE OLIVEIRA, L.G. No effects of noncytopathic bovine viral diarrhea virus type 2 on the reproductive tract of experimentally inoculated boars. Vet Microbiol. v.240, p.108512, 2020.

26. VANNIER, P.; LEFORBAN, Y.; CARNERO, R.; CARIOLET, R. Contamination of a live virus vaccine afainst pseudorabies (aujeszky's disease) by na ovine pestivirus pathogen for the. Ann de Rech v.19, n.4, p.283-290, 1988.

27. WALZ, P.H.; BAKER, J.C.; MULLANEY, T.P.; MAES, R.K. Experimental inoculation of pregnant swine with type I bovine viral diarrhoea virus. J. Vet. Med. v.51, n.4, p.191-193, 2004.

28. WEBER, M.N.; PINO, E.H.M.; SOUZA, C.K.; MÓSENA, A.C.S.; SATO, J.P.H.; DE BARCELLOS, D.E.S.N.; CANAL, C.W. Primeira evidência da infecção pelo vírus da diarreia viral bovina em javalis. Acta. Sci. Vet. v.44, p.1-5, 2016.

29. WEINSTOCK, D.; BHUDEVI, B.; CASTRO, A. Single-tube single-enzyme reverse transcriptase PCR assay for detection of BVDV in pooled bovine serum. J. Clin. Microbiol. v. 39, p.343346, 2001. 